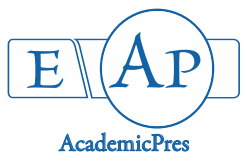

Akogwu MS et al. (2020)

Notulae Scientia Biologicae 12(4):773-780

DOI: $10.15835 / 12410718$

Research Article

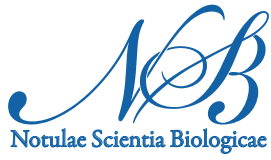

\title{
The influence of human chorionic gonadotropin on hormonal and haematological profile of postpubertal male albino rats exposed to chronic oral administration of alcohol
}

\author{
Martins S. AKOGWU, Chukwuka N. UCHENDU, Rita I. ODO* \\ University of Nigeria, Department of Veterinary Physiology and Pharmacology, Nsukka, \\ Nigeria; martinee4real@gmail.com; chukwuka.uchendu@unn.edu.ng; rita.odo@unn.edu.ng(*corresponding author)
}

\begin{abstract}
This study evaluated the influence of human chorionic gonadotropin on hormonal and haematological profile of postpubertal male albino rats exposed to chronic oral administration of alcohol. Twenty-four mature male albino rats were assigned to four groups $(n=6)$. Group A was the control, given distilled water, Group B was given $30 \%$ ethanol $(8 \mathrm{ml} / \mathrm{kg}$ ) orally 3 times a week, Group $\mathrm{C}$ was given human chorionic gonadotropin $(\mathrm{HcG})(50 \mathrm{IU} / \mathrm{kg})$ subcutaneously 3 times a week and Group D was given $\mathrm{HcG}(50 \mathrm{IU} / \mathrm{kg})$ subcutaneously + $30 \%$ ethanol $(8 \mathrm{ml} / \mathrm{kg})$ orally 3 times a week. The study was for 10 weeks, and hormonal profile and haematology were determined. The follicle stimulating hormone of Group B decreased significantly $(\mathrm{P}<0.05)$ when compared to Groups A, C and D. The luteinizing hormone was significantly lower $(\mathrm{P}<0.05)$ in Group B when compared to Groups A, C and D. The testosterone level was significantly higher $(\mathrm{P}<0.05)$ in Group D when compared to Groups A, B and C. The results obtained from haematology indicated that haemoglobin concentration of Group B was significantly lower $(\mathrm{P}<0.05)$ when compared to Groups A, C and D. Ethanol significantly reduced $(\mathrm{P}<0.05)$ platelets when compared to Groups $\mathrm{A}, \mathrm{C}$ and $\mathrm{D}$. There was a significant reduction $(\mathrm{P}<0.05)$ in the neutrophils and lymphocytes in Group B when compared to Groups A, C and D. The study showed that $\mathrm{HcG}$ improves the level of male hormones and haematology in postpubertal albino rats exposed to chronic alcohol administration.
\end{abstract}

Keywords: ethanol; haematology; HcG; hormones; male; rats

\section{Introduction}

Male hormones play an organizational role, priming the body to behave in a certain way once puberty begins, and an activational role, referring to changes in hormones during puberty that trigger behavioral and physical changes (Mooradian et al., 1987). At the onset of puberty, the hypothalamus secrets high pulses of gonadotropin-releasing hormone $(\mathrm{GnRH})$. In response, the pituitary gland releases follicle stimulating hormone (FSH) and luteinizing hormone (LH) into the male system (Mooradian et al., 1987). Follicle stimulating hormone, stimulates the Sertoli cells, which help to nourish the sperm cells that the testes produce, to facilitate spermatogenesis (Ronko and Llanos, 2000). Luteinizing hormone stimulates the interstitial cells, called Leydig cells, to produce and release testosterone into the blood (Petering and Brooks, 2017). 
Testosterone, the hormone responsible for the development of secondary sexual characteristics, stimulates spermatogenesis. (Skinner et al., 1989; Michael and Wojciech, 2006). Male hormones (androgens) promote erythropoiesis which is mediated by the ability of these steroids to increase erythropoietin (EPO) production (Gregory II and Finlay, 1999).

Alcohol is any organic compound in which the hydroxyl functional group $(-\mathrm{OH})$ is bound to a carbon. Alcohol (ethanol or ethyl-alcohol) is the ingredient found in beer, urine and spirits. It is formed when yeasts ferment (breaks down without oxygen) the sugars in different foods. Alcohol is classified as a "sedative hypnotic" drug which means it acts to depress the central nervous system (CNS) at high doses and at lower doses acts as a stimulant inducing feeling of euphoria and talkativeness. Consuming too much alcohol at one session can lead to drowsiness, respiratory depression, coma or even death. Alcohol has great effects on every organ in the body and these effects depend on the blood alcohol concentration (BAC) over a period of time (Brust, 2005).

Chronic consumption of alcohol lowers the level of testosterone through its conversion of one of its precursors into oestrogens through a process called aromatization. Testosterone is metabolized into oestradiol and similarly the immediate precursor of testosterone - androstenedione can be converted into a less potent oestrone. This conversion is greatly increased in chronic alcoholics and it has been discovered that individuals with alcoholic liver disease have increased levels of blood oestrogen (Van Thiel et al., 1974,1978; Gordon et al., 1976, 1978). Alcohol consumption results to certain abnormalities of red blood cells (RBCs) such as grossly enlarged RBCs as well as abnormally shaped RBCs that are subject to haemolysis, leading to anaemia (Duarte et al., 1995). Alcohol also interferes with normal production and function of white blood cells which form the body defense against microorganism and other foreign substances (Homaidan et al., 1984).

Human chorionic gonadotropin is a glycoprotein composed of 237 amino acids with a molecular mass of $36.7 \mathrm{KDa}$, approximately 14.5 alpha $\mathrm{HcG}$ and $22.2 \mathrm{KDa}$ beta HcG. It is a heterodimeric with an alpha subunit identical to that of luteinizing hormone $(\mathrm{LH})$, follicle stimulating hormone (FSH), thyroid stimulating hormone (TSH) and beta subunit that is unique to the HcG (Hoerman et al., 1990). It has LH like activity, hence it is used to stimulate ovulation in ovaries as well as testosterone production in the testis. Human chorionic gonadotropin is naturally produced in human placenta after implantation by the syncytiotrophoblast. It can be extracted from the urine of pregnant women or produced from cultures of genetically modified cells using recombinant DNA technology. Blood or urine tests for pregnancy measures $\mathrm{HcG}$ in concentrations commonly reported as thousandth international units per millilitre $(\mathrm{mIU} / \mathrm{mL})$. Human chorionic gonadotropin is extensively used for final maturation induction in lieu of LH, in the presence of one or more mature ovarian follicles, thus it triggers ovulation following its administration (Gregory II and Finlay, 1999; Cole, 2009). Alcohol has been reported to have deleterious effects on blood and male reproductive hormones, while $\mathrm{HcG}$ is known to be used in the treatment of sex hormone linked conditions such as undescended testes and poor libido in male (Allen et al., 1998). Male sex hormones have been shown to stimulate erythroid colony forming units in the bone marrow and promote their differentiation into erythropoietin responsive cells and testosterone enhances intestinal iron absorption, iron incorporation in red blood cells, and haemoglobin synthesis (Gregory II and Finlay, 1999). Hence, the aim of the present study was to evaluate the protective potentials of $\mathrm{HcG}$ on hormonal and haematological changes caused by alcohol in male rats.

\section{Materials and Methods}

\section{Chemicals and reagents}

Human chorionic gonadotropin ( $\mathrm{HcG}$ ) (Wellona Pharmaceuticals Ltd, India), Ethanol (Sigma, USA), Normal saline, WBC diluting fluid and Bouin fluid were obtained from the Department of Veterinary Physiology and Pharmacology, University of Nigeria, Nsukka. 
Animals

Twenty-four male albino Wistar rats (11-12 weeks of age) weighing 150-180g were used for this study. They were housed in the laboratory animal house of the Department of Veterinary Physiology and Pharmacology, University of Nigeria, Nsukka. They were kept in metallic cages and given water and feed (Chikun finisher) ad libitum. The rats were acclimatized for two weeks before commencement of the experiment. The investigation was carried out according to the approved procedure for the use and handling of laboratory animals as prescribed by the research and ethics committee of the University of Nigeria, Nsukka.

\section{Experimental design}

Twenty-four mature male albino rats were assigned to four groups $(n=6)$. Group A was the control, given distilled water, Group B was given $30 \%$ ethanol $(8 \mathrm{ml} / \mathrm{kg}$ ) orally 3 times a week, Group C was given human chorionic gonadotropin ( $\mathrm{HcG})(50 \mathrm{IU} / \mathrm{kg})$ subcutaneously 3 times a week and Group D was given $\mathrm{HcG}(50 \mathrm{IU} / \mathrm{kg})$ subcutaneously $+30 \%$ ethanol $(8 \mathrm{ml} / \mathrm{kg})$ orally 3 times a week. The study was for 10 weeks.

\section{Determination of parameters}

For hormonal assay, blood samples were collected from 16 rats from the orbital venous plexus, 4 samples per group into plain sample bottles (without EDTA) and the serum was used for assay of hormones: testosterone, follicle stimulating hormone (FSH) and luteinizing hormone ( $\mathrm{LH})$. The hormones were assayed using commercial kits of Enzyme linked immunosorbent assay (ELISA) (Rudolf, 2005).

The Packed Cell Volume (PCV) and haemoglobin concentration were determined by the microhaematocrit method of Coles, (1986) and cyanmethaemoglobin method of Kachmar, (1970) respectively. For red blood cell (RBC) and white blood cell (WBC) counts, the improved Neubauer haemocytometer was used, with formol citrate diluting fluid for RBC and Rus-Teller diluting fluid for WBC. The differential leucocyte counts were obtained by examining the thin blood smear stained with Leishman stain and observed under $\times 100$ magnification of the light microscope. The erythrocytic indices were deduced using routine standard procedures (Uchendu et al., 2015).

\section{Statistical analysis of data}

Data generated from the study were analysed using Graph pad ${ }^{\circledR}$ prism 6 statistical software. Results are presented as the means \pm standard error of the mean (SEM). Differences between the mean of the groups were compared using one-way analysis of variance (ANOVA) and Duncan's multiple range test. The statistical data were considered significant at $\mathrm{P}<0.05$.

\section{Results}

The results obtained from hormonal assay (Figure 1$)$ indicated a significant decrease $(\mathrm{P}<0.05)$ in FSH level in Group B when compared with Groups A, C and D. However, the value in Group D was significantly higher $(\mathrm{P}<0.05)$ when compared with Group C.

The mean value for LH was significantly lower $(\mathrm{P}<0.05)$ in Group B when compared with Groups A, $\mathrm{C}$ and $\mathrm{D}$. However, the value of Groups $\mathrm{C}$ and $\mathrm{D}$ were similar.

The testosterone concentration significantly decreased $(\mathrm{P}<0.05)$ in Group B when compared with Groups A, C and D. However, values for Groups $\mathrm{C}$ and $\mathrm{D}$ were significantly higher $(\mathrm{P}<0.05)$ when compared to Group $\mathrm{A}$, and there was a significant decrease $(\mathrm{P}<0.05)$ in Group $\mathrm{C}$ when compared with Group D. 


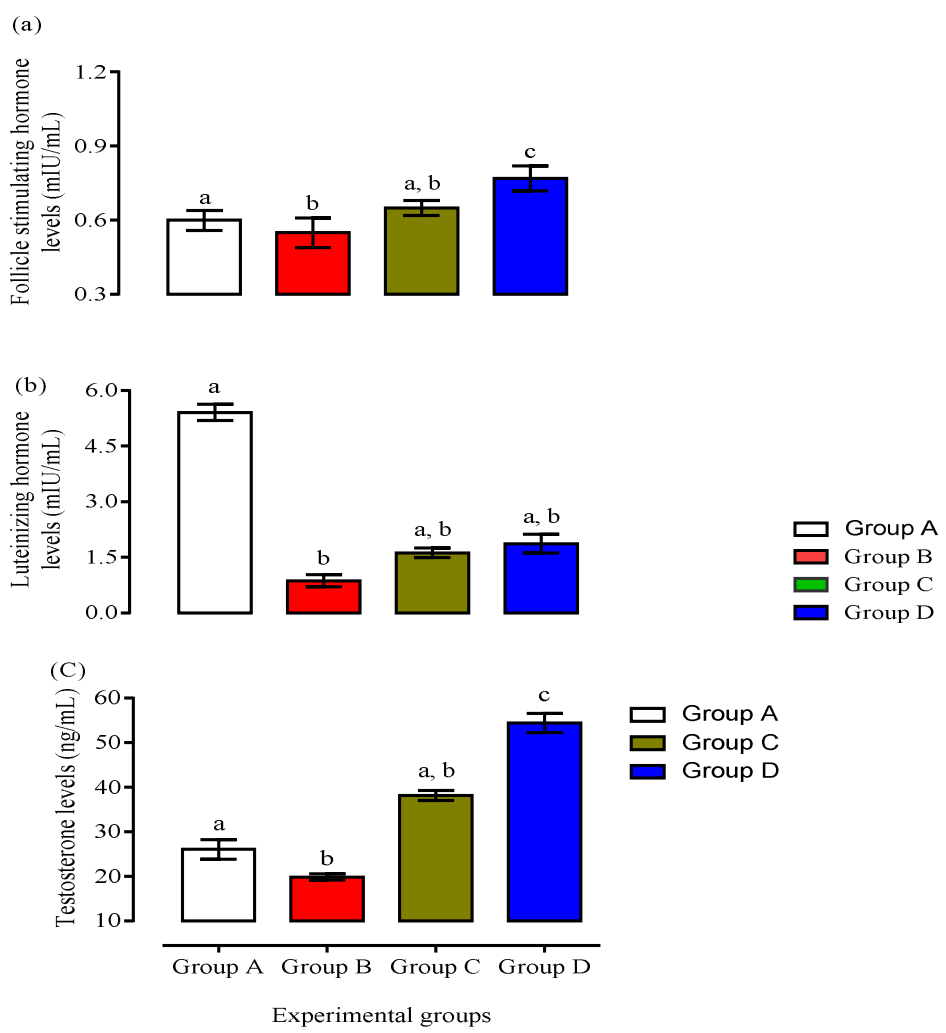

Figure 1. The effects of $\mathrm{HcG}$ on hormonal profile of male rats exposed to chronic oral administration of alcohol

Note: Group A: control; Group B: alcohol administration; Group C: human chorionic gonadotropin and Group D: alcohol + human chorionic gonadotropin

Bars with different letters indicate significant difference $(\mathrm{P}<0.05)$

The results obtained from the haematological parameters are presented in Table 1 . There was a significant decrease $(\mathrm{P}<0.05)$ in PCV of Group B $(42.0 \pm 1.47)$ when compared with Groups A $(46.0 \pm 1.41)$, C $(46.5 \pm 1.32)$ and $\mathrm{D}(45.8 \pm 0.85)$. However, the mean values for Groups $\mathrm{A}, \mathrm{C}$ and $\mathrm{D}$ were similar. The WBC count was significantly lower $(\mathrm{P}<0.05)$ in Group B when compared with Groups A, C and D. The mean value for Groups $\mathrm{C}$ and $\mathrm{D}$ were significantly higher $(\mathrm{P}<0.05)$ when compared with Group A. However, the values for Groups $C$ and $D$ were similar. The concentration of haemoglobin was significantly lower $(P<0.01)$ in Group B when compared with Group A. The mean value in Group B was significantly lower $(\mathrm{P}<0.05)$ when compared with Groups $\mathrm{C}$ and D. The values in Groups $\mathrm{C}$ and $\mathrm{D}$ were similar. The $\mathrm{RBC}$ count of Group B decreased significantly $(\mathrm{P}<0.05)$ when compared with Groups A, C and D. The mean values for Groups A, C and $\mathrm{D}$ were similar. The mean value of platelet count was significantly lower $(\mathrm{P}<0.01)$ in Group $\mathrm{B}$

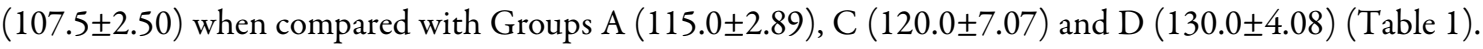
The value in Groups $C$ and $D$ were significantly higher $(\mathrm{P}<0.05)$ when compared to Group A. However, the mean value of Group $D$ was significantly higher $(\mathrm{P}<0.05)$ when compared to Group C. Neutrophils count was significantly lower $(\mathrm{P}<0.01)$ in Group B when compared with Groups A, C and D. The mean values for Groups $\mathrm{C}$ and $\mathrm{D}$ were significantly higher $(\mathrm{P}<0.05)$ than the normal (control). The values in Group D was significantly higher $(\mathrm{P}<0.05)$ when compared to Group $\mathrm{C}$. The lymphocyte count decreased significantly $(\mathrm{P}<0.001)$ in Group B when compared with Groups A, C and D. The mean value in Group C was significantly lower $(\mathrm{P}<0.05)$ when compared to Group A, Group A was similar to Group D. The value in Group C was significantly lower $(\mathrm{P}<0.01)$ when compared with Group D. 
Table 1. The effects of $\mathrm{HcG}$ on haematological profile of male rats exposed to chronic oral administration of alcohol

\begin{tabular}{|l|c|c|c|c|}
\hline \multicolumn{1}{|c|}{ Parameters } & Group A & Group B & Group C & Group D \\
\hline Packed cell volume (\%) & $46.0 \pm 1.41^{\mathrm{a}}$ & $42.0 \pm 1.47^{\mathrm{b}}$ & $46.5 \pm 1.32^{\mathrm{a}}$ & $45.8 \pm 0.85^{\mathrm{a}}$ \\
\hline White blood cell count $\left(\times 10^{9} / \mathrm{l}\right)$ & $8.55 \pm 0.29^{\mathrm{a}}$ & $7.15 \pm 0.21^{\mathrm{b}}$ & $10.50 \pm 0.17^{\mathrm{c}}$ & $10.95 \pm 0.21^{\mathrm{c}}$ \\
\hline Haemoglobin conc. $(\mathrm{g} / \mathrm{dl})$ & $23.08 \pm 0.87^{\mathrm{a}}$ & $16.40 \pm 0.47^{\mathrm{b}}$ & $17.48 \pm 0.67^{\mathrm{c}}$ & $17.73 \pm 0.90^{\mathrm{c}}$ \\
\hline Red blood cell count $\left(\mathrm{x} 10^{12} / \mathrm{l}\right)$ & $7.30 \pm 0.06^{\mathrm{a}}$ & $4.63 \pm 0.05^{\mathrm{b}}$ & $7.50 \pm 0.04^{\mathrm{a}}$ & $7.53 \pm 0.03^{\mathrm{a}}$ \\
\hline Platelet count $\left(\times 10^{9} / \mathrm{l}\right)$ & $115.0 \pm 2.89^{\mathrm{a}}$ & $107.5 \pm 2.50^{\mathrm{b}}$ & $120.0 \pm 7.07^{\mathrm{c}}$ & $130.0 \pm 4.08^{\mathrm{d}}$ \\
\hline Neutrophils count $(\%)$ & $63.0 \pm 2.08^{\mathrm{a}}$ & $55.5 \pm 2.22^{\mathrm{b}}$ & $66.50 \pm 1.50^{\mathrm{c}}$ & $69.50 \pm 1.89^{\mathrm{d}}$ \\
\hline Lymphocyte count $(\%)$ & $39.50 \pm 2.36^{\mathrm{a}}$ & $27.50 \pm 1.50^{\mathrm{b}}$ & $32.00 \pm 1.82^{\mathrm{c}}$ & $38.00 \pm 2.94^{\mathrm{a}}$ \\
\hline
\end{tabular}

Data on the same row with different superscript letters indicate significant difference $(\mathrm{P}<0.05)$

\section{Discussion}

The significant reduction in the levels of FSH, LH and testosterone concentrations in Group B when compared with Groups A, C and D may be attributed to the fact that alcohol inhibits the production and release of LH by inhibiting the movement of an enzyme protein kinase $\mathrm{C}$ from within the LH producing cells to the cell surface. This movement is essential for $\mathrm{GnRH}$ to stimulate the production and release of LH (Steiner et al., 1997). Alcohol interferes with the complex mechanism in the chain of events involved in the binding of GnRH to the pituitary cell for the release of Luteinizing hormone (Van Thiel et al., 1974, 1978; Gordon et al., 1976, 1978; Salonen and Huhtaniemi, 1990). Alcohol also adversely affects Leydig cells resulting in reduced testosterone levels in the blood. It impairs the function of the testicular Sertoli cells that play an important role in sperm cell maturation (Emanuele and Emanuele, 1998). It was noted in this present study that testosterone level was significantly higher in Groups C and D (Figure 1) when compared to Groups A and B. This could infer that human chorionic gonadotropin enhances the stimulatory effect of LH surge in the release of testosterone by the Leydig cells in the testicular interstitium. This fits well with the findings of Skinner et al., (1989); Michael and Wojciech, (2006) that a surge of luteinizing hormone promotes testosterone release which, in combination with the presence of follicle stimulating hormone, are needed to support spermatogenic process. In Group D, human chorionic gonadotropin also stimulated an increase in testosterone production by the Leydig cells. This increase in testosterone biosynthesis may be responsible for the drastic reduction in $\mathrm{LH}$ in this group through inhibition by negative feedback mechanism (Figure 1). Moreover, the reduction in serum testosterone level in Group B should expectedly, have led to an elevation in serum LH concentration even higher than in the control, due to the inadequate levels of testosterone to shut off further LH production from the pituitary gland. The increase in LH would have continued to stimulate the Leydig cells to make up for the short fall in testosterone production in a homeostatic manner. The over stimulation could even cause hypertrophy of the Leydig cells (Birken et al., 1990; Ronco and Llanos, 2000). This, however, was not the case most likely due to the modulatory effect of alcohol on gonadotropin secretion. There is evidence that alcohol suppresses pituitary LH secretion via its inhibitory effect on LHRH release by the hypothalamus (Retorri and McCann, 1997). This may have accounted for the low levels of LH and testosterone in this group (that is, Group B). Earlier reports on chronic alcohol consumption indicated that ethanol induces changes in testicular activities in mature male rats. This corroborates the findings of Van Thiel et al. (1978) who stipulated that ethanol has a direct effect on the Leydig cells of the testis by decreasing LH level and a decrease in serum testosterone level through inhibition of testosterone biosynthesis. The Leydig cells are responsible for the production of testosterone in the presence of LH and supported by Sertoli cells. These Sertoli cells secretes androgen binding proteins (ADP) in the lumen of the seminiferous tubules which causes an increase in intratesticular testosterone concentration, it is this increase coupled with FSH that is needed for spermatogenesis. 
The significant decrease in haemoglobin concentration in Group B in this study may be that excessive alcohol consumption results in suppression of blood cell production which reduces the number of blood cell precursors in the bone marrow and causes characteristic structural abnormalities in these cells resulting in nonfunctional mature red blood cells which adversely affects the concentration of haemoglobin (Ballard, 1989; 1993). The significant reduction in concentration of haemoglobin in Group B when compared with Groups A, C may have reduced the oxygen carrying capacity of the blood in that group, as haemoglobin is the pigment in blood that binds with oxygen. Also, the formation of red blood cell precursors with large vacuoles often leads to premature and accelerated cell death. It was also observed in this study that packed cell volume (PCV) and red blood cell $(\mathrm{RBC})$ count were significantly $(\mathrm{P}<0.05)$ reduced in Group B when compared with other groups. This significant reduction in PCV and RBC counts could be that alcohol causes the production of defective red blood cells that are rapidly destroyed prematurely leading to anaemia (Ballard, 1993). Results obtained from this study correlates with the findings of Vonghia et al. (2008) who stipulated that chronic alcohol consumption results in certain blood abnormalities leading to anaemia (low haemoglobin).

Present findings indicate a significant reduction in leukocytes, neutrophils and lymphocyte counts in Group B which may be a consequence of alcohol causing suppression of the immune system. It interferes with the normal production and function of the white blood cells which forms the body defence against microorganisms and other foreign substances. Alcohol also impairs the function of neutrophils which is the primary defence against microorganisms and lymphocytes that mediates immune response (McFarland and Liebre, 1963). Neutrophils and lymphocyte counts were significantly reduced in Group B when compared to other groups which could be attributed to the deleterious effects of alcohol on these cells. The white blood cells also decreased significantly $(\mathrm{P}<0.05)$ in Group B when compared with Groups A, C and D which indicates that alcohol decreases body immunity. In Groups $C$ and $D$, the concentration of neutrophils, lymphocytes and leucocytes was relatively high, which may indicate that $\mathrm{HcG}$ enhances immunity and body defence against microorganisms. Reduction in platelet counts in Group B could be the resultant effect of alcohol on platelets, this reduces the ability of the blood to clot. It is the function of platelets to form plugs that blocks ruptured blood vessels and capillaries (Lindenbaum and Hargrove, 1968; Duarte et al., 1995). The mean value of platelet counts in Group $\mathrm{C}$ was significantly higher $(\mathrm{P}<0.01)$ when compared with Groups $\mathrm{A}$ and $\mathrm{B}$, this may be that human chorionic gonadotropin improves platelet counts. However, Group D has the highest mean value of platelet counts which may be as a result of the influence of human chorionic gonadotropin in response to damage induced by alcohol to improve platelet counts. The mean values for the haematological parameters were relatively higher in Groups $\mathrm{C}$ and D except for haemoglobin concentration, where Group C and D were similar. This shows that $\mathrm{HcG}$ had a positive influence on haematological profile.

\section{Conclusions}

The sexual behaviour and phenotypic appearances of an animal exposed to long term alcohol consumption may appear to be normal but the haematological, immunological and endocrine profile could be seriously compromised. This study has demonstrated that human chorionic gonadotropin has a positive influence on the haematological and hormonal profile of male albino rats exposed to chronic oral alcohol consumption.

\section{Authors' Contributions}

Research conceptualization: CNU. Supervision, project administration, validation, visualization, writing - review and editing: CNU and RIO. Data curation, formal analysis, investigation and methodology: RIO and AMS. Resources: CNU, RIO and AMS. Software and writing - original draft: AMS. 
All authors read and approved the final manuscript.

\section{Ethical approval}

This research was approved by research and ethics committee of University of Nigeria, Nsukka. Ethical review was in conformity with the norms of researches involving animals.

\section{Acknowledgements}

This research received no specific grant from any funding agency in the public, commercial, or not-forprofit sectors.

\section{Conflict of Interests}

The authors declare that there are no conflicts of interest related to this article.

\section{References}

Allen SB, Helena WR, Richard JS (1998). Gonadotropin therapy in men with isolated hypogonadotropic hypogonadism: The response to human chorionic gonadotropin is predicted by initial testicular size. Journal of Clinical Endocrinology and Metabolism 66(6):1144-1151. https://doi.org/10.1210/jcem-66-6-1144

Ballard HS (1989). Haematological complication of alcoholism. Clinical and Experimental Research 13(5):706-720. https://doi.org/10.1111/j.1530-0277.1989.tb00408.x

Ballard HS (1993). Alcohol, bone marrow and blood. Alcohol Health and Research World 17(4):310-315.

Birken S, Krichevsky A, O'Connor J, Lustbader J, Canfield R (1990). Chemistry and immunochemistry of hCG, its subunits and its fragments. Glycoprotein Hormones 45-61.

Brust JCM (2005). Alcoholism. In: Rowland LP (Ed). Merritt's neurology (11th ed), Philadelphia, Lippincott Williams and Wilkins pp 111-122.

Cole LA (2009). New discoveries on the biology and detection of human chorionic gonadotropin, Reproductive biology. Endocrinology 7:80-89. https://doi.org/10.1186/1477-7827-7-8

Coles EH (1986). Determination of packed cell volume. Veterinary Clinical Pathology 17-19.

Duarte APT, Dong QS, Young, Abi YJ, Myers AK (1995). Inhibition of platelet aggregation in whole blood by alcohol. Thrombosis Research 78(2):107-115. https://doi.org/10.1016/0049-3848(95)00039-9

Emanuele MA, Emanuele NV (1998). Effect of alcohol on spermatogenesis. Alcohol Health and Research World 22(3):195-201.

Gordon CG, Altman K, Southren AL, Rubin E, Lieber CS (1976). The effects of alcohol administration on sex hormone metabolism in normal men. New England Journal of Medicine 295:793-797. https://doi.org/10.1056/NEJM197610072951501

Gordon GS, Southren AL, Lieber CS (1978). The effects of alcoholic liver disease and alcohol ingestion on sex hormone levels. Alcoholism Clinical and Experimental Research 2:259-263. https://doi.org/10.1111/j.15300277.1978.tb05809.x

Gregory II, Finlay IL (1999). Alpha fetoprotein and beta human chorionic gonadotropin: their clinical significance as tumour markers. Drugs 57(4):463-7. https://doi.org/10.2165/00003495-199957040-00001

Hoermann R, Spoettl G, Moncayo R, Mann K (1990). Evidence for the presence of human chorionic gonadotropin HCG and free $\beta$ subunit of HCG in the human pituitary. Journal of Clinical Endocrinology and Metabolism 71(1):17986. https://doi.org/10.1210/jcem-71-1-179 
Homaidan FR, Kricka LJ, Whitehead TP (1984). Morphology of red blood cells in alcoholics. The Lancet 323(8382):913914.

Kachmar JF (1970). Determination of blood haemoglobin by the cyanomethaemoglobin procedure. In: Tietz NW (Ed). Fundamentals of clinical chemistry. W.B. Saunders Company, Philadelphia, pp 268-269.

Lindenbaum J, Hargrove RL (1968). Thrombocytopeania in alcoholics. Annals of Internal Medicine 68:526-532. https://doi.org/10.7326/0003-4819-68-3-526

McFarland E, Liebre EP (1963). Abnormal leukocyte response in alcoholism. Annals of Internal Medicine 59:865-877. https://doi.org/10.7326/0003-4819-59-6-865

Michael HR, Wojciech P (2006). Histology text and atlas, $5^{\text {th }}$ edition. Lippincott Williams and Wilkins pp 62-69.

Mooradian AD, Morley JE, Korenman SG (1987). Biological actions of androgens. Endocrine Reviews 8:1-28. https://doi.org/10.1210/edrv-8-1-1

Petering RC, Brooks NA (2017). Testosterone therapy: Review of clinical applications. American Family Physician 96:441-449.

Rettori V, McCann SM (1997). The mechanism of action of alcohol to suppress gonadotropin secretion. Molecular Psychiatry 2:350-354.

Ronco AM, Llanos MN (2000). Effect of human chorionic gonadotropin derivatives on Leydig cell function. Hormone Research in Paediatrics 54(4):157-163. https://doi.org/10.1159/000053252

Rudolf ML (2005). Enzyme immunoassay (EIA)/enzyme-linked immunosorbent assay (ELISA). Clinical Chemistry 51(12):245-248. https://doi.org/10.1373/clinchem.2005.051532

Salonen I, Huhtaniemi I (1990). Effect of chronic ethanol diet on pituitary-testicular function of rat. Biology of Reproduction 42:55-62. https://doi.org/10.1095/biolreprod42.1.55

Skinner MR, Mclachlan RI, Bremner WJ (1989). Stimulation of Sertoli cells inhibin secretion by the testicular paracrine factor PModS. Molecular and Cellular Endocrinology 66(2):239-249. https://doi.org/10.1016/03037207(89)90036-1

Steiner J, Kirsteins L, LaPaglia N, Lawrence A, Williams D, Emanuele N, Emanuele M (1997). The effect of acute ethanol $(\mathrm{EtOH})$ exposure on protein kinase C (PKC) activity in anterior pituitary. Alcohol 14(3):209-211. https://doi.org/10.1016/s0741-8329(96)00113-9

Uchendu CN, Ezeasor DN, Obidike IR, Odo RI, Francis B, Ejembi JI (2015). The influence of natural unilateral cryptorchidism on sperm reserves and haematology of West African Dwarf(WAD) goats (Capra aegagus hircus). IOSR Journal of Agriculture and Veterinary Science 8:21-28.

Van Thiel DH, Lester R, Vaitukaitis J (1978). Evidence for a defect in pituitary secretion of LH in chronic alcoholic men. The Journal of Clinical Endocrinology and Metabolism 47:499-507.

Van Thiel DH, Lester R, Sherins RJ (1974). Hypogonadism in alcoholic liver disease. Evidence for a double defect. Gastroenterology 67:1188-1199.

Vonghia L, Leggio L, Ferrulli A, Bertini M, Gasbarrini G, Addolorato G, Alcoholism Treatment Study Group (2008). Acute alcohol intoxication. European Journal of Internal Medicine 19(8):561-567. https://doi.org/10.1016/j.ejim.2007.06.033

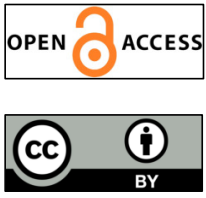

The journal offers free, immediate, and unrestricted access to peer-reviewed research and scholarly work. Users are allowed to read, download, copy, distribute, print, search, or link to the full texts of the articles, or use them for any other lawful purpose, without asking prior permission from the publisher or the author.

License - Articles published in Notulae Scientia Biologicae are Open-Access, distributed under the terms and conditions of the Creative Commons Attribution (CC BY 4.0) License.

(c) Articles by the authors; SHST, Cluj-Napoca, Romania. The journal allows the author(s) to hold the copyright/to retain publishing rights without restriction. 